Afrika Focus, Vol.8, Nr.2, 1992, pp 93-103

\title{
WANJIRU'S SEARCH FOR SELF IN NGUGI WA THIONG'O'S "MINUTES OF GLORY"
}

\section{Owen G. MORDAUNT}

English Department

University of Nebraska at Omaha

Omaha, Nebraska 68182-0175, USA

\section{SUMMARY}

This paper deals with Ngugi wa Thiong'o's portrayal of the protagonist in his short story "Minutes of Glory". Wanjiru finds herself trapped in an urban setting and is a victim of her situation and low self-esteem. The story is a poignant and touching study of this young woman who is battling with an identity problem and is seeking acceptance in a post-independence setting where women are exploited by men of the New Africa elite. She is regarded as "a wounded bird in flight: a forced landing now and then but nevertheless wobbling from place to place ..." The story affirms female self-realization rather than perpetual self-alienation, and that validates the persistence in attaining her desired goal.

KEY WORDS: Kenya, literature, psychology, short story

\section{INTRODUCTION}

The male protagonist is the focus of a large body of African literature in English, the general theme being the conflict with the inroads of Westernization upon his world.(1) In the works of the contemporary Senegalese novelists Ousmane Sembene and Aboulaye Sadji, however, women are given a significant role.(2) Karen Smiley-Wallace's encapsulation of African women is worth noting: 
"Through their vast and colorful tableaux of women figures (market women, wives, mothers, daughters, political leaders, prostitutes, teachers, secretaries, etc.) Sadji and Sembene illustrate the tormenting world of the double self, anxiety and alienation. Although the notion of duality is expressed differently by each character, they are all linked by two factors: their intense struggle for survival ... and the disintegration of their sense of 'africanite"' (1986: 65).

Henri Lopes of Congo-Brazzaville is an example of another writer whose works are devoted to women.(3) Also, women are assigned a major role in most works by Kenyan Ngugi wa Thiong'o. For example, the heroines Muthoni in The River Between, Mumbi in A Grain of Wheat, and Wanja and Nyakinua in Petals of Blood are heroines who are committed to preserving traditional values. In his novel, Petals of Blood, Nguhi depicts Wanja and Nyakinua as powerful Gikuyu women; and, according to Charles Nama, Wariinga, in Devil on the Cross, like Nyakinyua in Petals of Blood, represents the struggle against corruption and adulteration of foreign culture ... primarily against the neo-colonial elites which have subjugated women to secondary roles which are diametrically opposed to their revered status in traditional Gikuyu society (1978: 146-147).

The study of the African woman in African literary criticism is also in line with the African feminist theoretical framework. A summary of current African feminist criticism is outlined in Carole Boyce Davies' introduction to Ngambika: Studies of Women in African Literature (pp. 1-23). According to Davies (1986: 12), "African literary criticism ... if it is unbiased ... will have to come to grips with issues such as the treatment of women characters."

\section{THE AUTHOR}

The focus of this article is Wanjiru, the protagonist, in Ngugi wa Thiong'o's short story "Minutes of Glory" (hereafter cited as $\underline{\mathrm{MoG}}$ ) in African Short Stories (Chinua \& Innes 1985: 71-84). At this point, however, a some biographical information is provided for purposes of the placement of the author.

Ngugi is regarded as Kenya's most renowned writer. He was born in Limuru, near Nairobi in 1938. He was called James Ngugi until March 1970 when he changed his name to the traditional name Ngugi wa Thiong'o. Many of his works are published under his former name, James Ngugi. He received his education at a church-run primary school near his home, an independent Gikuyu school providing education relevant to the African setting, and a parochial high school. After completing his high school education, he attended Makerere College in Kampala, 
Uganda, as an honours student of English. Makerere College was at that time still a college of the university of London, and it was here that Ngugi first began to write. His play The Black Hermit was put on by the Uganda National Theatre in 1962, but it was not until 1968 that it was published when Ngugi had already gained a reputation as a novelist. His first novel, Weep Not. Child was published in 1964. His other works are The River Between (1965), A Grain of Wheat (1967), This Time Tomorrow, reprinted in Short African Plays (1972), Homecoming (1972), The Trial of Dedan Kiumathi - with Micere Githae Mugo - (1976), Petals of Blood (1977), Ngaahika Ndeenda (1980), Caitaani Mutharaba-Ini (1980) which he translated into English under the title Devil on the Cross (1982). He also published two works of non-fiction, another anthology of essays called Writers on Politics (1981), and a record of his experiences and thoughts while imprisoned entitled Detained: A Writer's Prison Diary (1981). His works cover three encounters with European colonialization: slavery, colonialism, and neocolonialism.

After graduating from the Makerere College he worked briefly for The Daily Nation in Nairobi before enrolling at Leeds University in England. On his return to Kenya from England in 1968, he was appointed lecturer in the Department of English at the University of Nairobi. In 1969 he resigned his lectureship in protest against the governments' involvement with academic freedom. That same year Ngugi left Nairobi for Northwestern University in the U.S.A. where he lectured and studied and wrote his fourth novel Petals of Blood.

\section{DISCUSSION}

Wanjiru, the chief character in "Minutes of Glory", is a victim both of circumstances and low-self image, and the story is a moving psychological study of this young woman, who is in search of self and approval. Wanjiru's perception of herself appears to be a requisite for acceptance and belonging in her world. Obviously, she has embarked upon a journey in search of self since she desires to find the root cause of her alienation. Her search is constituted by the following stages: endeavoring to come to terms with the meaning of her name, wandering from place to place, examining self, fantasizing, experiencing a surface relationship with a man, and, finally, triumphing (to a degree).

Told from the omniscient perspective, the story follows her experiences through bars around Limuru and also in Ilmorog. She is a school drop-out because her parents lacked money. As a naive young rural woman desperate for employment, she falls prey to the deceit of an exploiter who promises to find her a job but, instead, dumps her after a one-night stand. Consequently, she finds herself trapped 
in a situation completely foreign to her experience and resorts to prostitution, a profession that is dehumanizing to womanhood.

The exposition of the story sets the tone for the story by introducing the protagonist and suggesting the conflict under which she chafes. Her Christian name, Beatrice, which means "Blessed One" is contradicted by her very existence. Her miserable condition reflects what Bantu people regard as "darkness" or misfortune and underscores the overall mood of the story; no wonder her attempt at making it in life is futile. Nguhi explains:

"Her name was Wanjiru. But she liked better her Christian one, Beatrice. It sounded more pure and more beautiful. Not that she was ugly, but she could not be called beautiful either. Her body, dark and full fleshed, had the form, yes, but it was as if it waited to be filled by the spirit. She worked in beer-halls where the sons of women came to drown their inner lives in beer cans and froth. Nobody seemed to notice her. Except, perhaps, when a proprietor or an impatient customer called out her name, Beatrice; then other customers would raise their heads briefly, a few seconds, as if to behold the bearer of such a beautiful name, but not finding anybody there, they would resume their drinking, their ribald jokes, their laughter and play with the other serving girls" (MoG 71).

In traditional African culture, nomenclature is significant in that the name borne is supposed to reflect the personality of the person, and this is not the case here. From the perspective of customers to the beerhalls, who are the people who seem to matter in terms of Wanjiru's self-concept and belonging, the name "Beatrice" is, instead, ironic; it practically has no referent.

As the story unfolds, Wanjiru's incapability of holding down a job for any significant length of time is noticeable and is a symptom of her instability. She is accurately described as " $a$ wounded bird in flight: a forced landing now and then but nevertheless wobbling from place to place so that she would variously be found in Alaska, Paradise, The Modern, Thome and other beer-halls all over Limuru" (MoG 72). Her search seems to be an interminable journey: she is unsuccessful in the urban centers, so she tries the sprawling townships in the vicinity, but "everywhere the story [is] the same ... occasionally she ... [gets] a client; but none [cares] enough for her as she would ... [like], none really [wants] her enough to fight over her. She [is] always the hard-up customer's last resort" (MoG 71-72). At times she is dismissed from a job by an angry boss because of her failure to "attract enough customers" (MoG 72); success as a prostitute means more income for her boss. But she hopes that by wandering from place to place she will 
eventually find her roots. But she never finds herself in control of her life and of her situation; no wonder she envies rival prostitutes, who she thinks are successes.

In her endeavor to find a solution to her misfortunes, she engages in a process of self-examination and comparison with the other young women, but she fails to perceive any significant differences between herself and the latter. Ironically, she is more attractive than some, so she cannot fathom why they are desirable and she is not: "girls even more decidedly ugly than she [are] fought over by numerous claimants at closing hours. What do they have that I don't have? she ... [asks] herself, depressed" (MoG 71). Later, because of her concern that her appearance is a major cause of her rejection by men, she will attempt a metamorphosis of her looks.

Nyaguthii is the girl whose intimidation is most unbearable, for Wanjiru erroneously sets Nyaguthii up as a model because she assumes that the latter has control of her life, and Wanjiru herself doesn't. She sees in this person "the girl she would like to be", someone who is "both totally immersed in and yet completely above the underworld of bar and violence and sex." Outwardly, Nyaguthii is haughty, distant, and even fights men, but she always has them in her "courtyard", and they still bring her "propitiating gifts which she accepts as of right" (MoG 72). To Wanjiru, Nyaguthii is the exemplification of a "free woman" but Nyaguthii is "also a bird in flight" who hungers "for change and excitement: new faces and new territories for her conquest. Wanjiru [resents] her very shadow" because wherever she goes, Nyaguthii's visibility is unavoidable (MoG 72). In a sense Nyaguthii is a kind foil for Wanjiru, and, ironically, in her darkest hour, she will turn to Nyaguthii for help. Even though she discovers that her imagined rival does not fit the perceived description, she learns from Nyaguthii that she, too, can relate to men with a certain air of indifference, thus freeing herself from her mental bondage.

Although Wanjiru's greatest desire is to find a bar-kingdom where she would reign without the interference of other women, bliss for her is also contingent upon being physically attractive so that she is enticing to men. Her attitude is reminiscent of that of Madame Loisel, in "The Necklace" by Guy de Maupassant, who "longed so eagerly to charm, to be desired, to be wildly attractive and sought after" (1989: 832). Wanjiru, therefore, tries two approaches to mask her unattractive image. First, she tries clothes, but she does not earn enough money both to buy clothes and to pay for her lodgings. Since she, like Wariinga in Ngugi wa Thiong'o's Devil on the Cross, loathes her blackness, attributing it to her misfortunes, she attempts to mask her unattractiveness by applying Ambi, a skin-lightening cream, 
"for had she not seen girls blacker than herself being transformed overnight from ugly sins into white stars by a touch of skin-lightening creams? And men would ogle them, would even talk with exaggerated pride of their newborn girl friends ... they always went for a girl with an Ambi-lightened skin and head covered with a wig made in imitation of European or [East] Indian hair" (MoG 72).

This searing of her black skin could be interpreted as an attempt by Wanjiru to obliterate her negative image, hoping that a new Wanjiru would emerge at the end of the process. But no matter how she uses her creativity to change her exterior image and accommodate her perception of acceptance, she is still unhappy and feels alienated. All this does nothing to camouflage her low self-image.

It is during her experimentation with the skin-lightening cream that she feels her most profound humiliation. The owner of Starlight Bar and Lodging in Ilmorog, after being turned down by Nyaguthii, approaches Wanjiru and tries to seduce her, but she refuses, thus retaining "a fierce pride even at the bottom of the heap", (Cook \& Okenimpke 1983: 149-150) for "she could not, she would not bring herself to accept that which had recently been cast aside by Nyaguthii" (MoG 74). As a consequence of her action, Wanjiru is fired by her boss. This uncompromising reaction to her boss's attempted sexual harassment surprises her, and is a foreshadowing of her future self-assertiveness, an inner strength hitherto not seen in her personality.

As the story unfolds, Wanjiru begins to view herself from a different light, thus making some progress toward the resolution. When she is out of a job, she looks at herself in the mirror and observes that she has aged, "hardly a year after she has fallen from grace" (MoG 75). She also realizes that she is scrupulous, and "somehow [has] a horror of soliciting lovers or directly bartering her body for hard cash" (MoG 74-75). Deep down what the real Wanjiru "wanted was decent work and a man or several men who cared for her. Perhaps she took that need for a man, for a home and a child with her to bed. Perhaps it was this genuine need that scared off men who wanted other things from barmaids" (MoG 75).

No wonder she is a failure as a woman of the street, and, according to Cook and Okenimpke, it is "because her romantic soul yearns for a true love relationship and makes her hate this dreary imitation, thus accentuating her lack of seductive graces" (1983: 149). The author seems to unveil a major reason for Wanjiru's lack of success: she cannot substitute fake relationships for genuine love. The implication here is that the New Africa elite is bent on exploiting women for their own gratification and not interested in germaine relationships between men and women as prescribed by traditional African culture. 
Now at the end of hope, she begins to fantasize about home, her roots. The reference to the protagonist's background is significant in that "Minutes of Glory" is in part a political statement against the vices of Westernization. Westernization is portrayed as a blight that has corrupted the earthly paradise, that is, communal rural African life and all its ramifications, thus the reference: "Her mother's village in Nyeri seemed the sweetest place on God's earth. She would invest the life of her peasant mother and father with romantic illusions of immeasurable peace and harmony. She longed to go back home to see them. But how could she go back with empty hands? In any case the place was now a distant landscape in the memory. Her life was here in the bar among the crowd of lost strangers. Fallen from grace ... She was part of the generation which would never again be one with the soil, the crops, the wind and the moon" (MoG 75).

It is against this background (the communal existence versus the brutal market economy) that she reflects on the life that could have been hers, a life of security and happiness. She is like other African women characters who often have found themselves cut off from their past and trapped within a system of ruthless exploitation.

Ngugi shows that separation from the fabric of African traditional community life is a key factor contributing to the exploitation of African women. Nobody can protect them once they are uprooted from home and all it represents. Nguhi, therefore, wants us to interpret this sense of displacement as a result of the influence of foreign values which are brought upon by Westernization. She inadvertently has relegated herself to the position of an outsider to her parents' community; thus she "anticipates Wanja in Petals of Blood" (Cook \& Okenimpke 1983: 149) and postdates Jagua Nana, the heroine in Cyprian Ekwensi's Jagua Nana. Wanjiru's life as prostitute is anathema to the traditional values of her people; consequently, she, Wanjiru, has condemned herself to a fruitless pursuit of life and love. She even attempts suicide but does not go through with it (MoG 75).

Wanjiru's plight seems to reflect a larger sterility affecting women attempting to exist in an environment unnatural to the African way of life. A writer like Okot p'Bitek is supportive of this view; in Song of Lawino (1966), for example, he puts reactionary words in the mouth of the heroine, Lawino:

Listen Ocol, my old friend

The ways of our ancestors

Are good,

Their customs are solid 


\author{
And not hollow \\ They are thin, not easily breakable \\ They cannot be blown away \\ By the winds \\ Because their roots are deep in the soil \\ I do not understand \\ The way of foreigners \\ But I do not despise their customs \\ Why should you despise yours? (p. 29)
}

Lawino despises modern women and rejects the concept of beauty held in the West but, instead, promotes the traditional way of life. For other African writers, however, the rural habitat is no Shangri-la; they perceive some aspects of the traditional society as being discriminatory against women: Westernization has only sharpened their lot. Therefore, some city women are portrayed as being free from the bondage of traditional life and marriage practices. Unfortunately, in African fiction most urban women are not held in high regard: they are stereotyped as "prostitutes and mistresses" (Mutiso 1974: 72). These prejudices are however also reflected in Ngugi wa Thiong'o's works.

To return to "Minutes of Glory", we notice that the opening of a new bar, Treetop Bar, in Ilmorog offers Wanjiru temporary relief. She is employed as a sweeper and bedmaker and feels closer to greatness since she now makes beds for big men whom she has previously known only as names. Her feelings of elation are, however, short-lived when Nyaguthii and the other girls flock to Treetop Bar from other bars. These girls are offered more prestigious jobs than Wanjiru, so they despise her for performing menial tasks for which she is paid a mere pittance. To escape from her misery, she resorts to illusion and fantasy, dreaming of lovers, sleek cars, smart clothes, fulfilled passions and lust. These fantasies merely provide a brief respite.

Then there is a glimmer of hope, but this hope is dashed by her perceived rejection by a man who is a big transporter of vegetables and one whom she sees as a fellow victim since he is not really one of the "big shots" whose recognition he is attempting to gain. She has yearned to talk to and confide in someone who would understand. Instead she is insulted by this truck-driver who falls sound asleep when she has been expecting to share verbally with him what is in her tormented heart, the very man who "Saturday after Saturday" has poured out his soul to her and has "paid for her human services" (MoG 80). At this climactic moment in the story, something in her snaps. All the anger of the year and a half that she has been on 
the road and all the bitterness against her humiliation are now directed at this man. The failure of this person, presumably the most able to commiserate with her and understand her situation, further emphasizes cultural disintegration because the friendship develops outside the confines of traditional cultural norms. She steals his money and then imposes herself on Nyaguthii, in desperation to talk to somebody. From the conversation it is clear that Wanjiru and Nyaguthii have all along had misconceptions about each other; they both have assumed that the other has control over her life. Wanjiru learns that Nyaguthii, even though she requires the attention of "those flattering eyes to make ... [her] feel ... [herself]", she [Nyaguthii] is free in terms of not being moved by men; "nothing interests" her (MoG 82). Wanjiru realizes that she too can be herself: free, whatever that implies in her situation. The conversation between Nyaguthii and Wanjiru does indicate an element of sisterhood solidarity.

When she goes to Nairobi to shop with the stolen money, Wanjiru looks in the mirror, this time at "her new self" and becomes aware of a new sense of power. Like Nguhi's other female characters who triumph in the end, Wanjiru finally achieves self-realization rather than perpetual alienation; even though it does not appear that she seeks an alternative life-style, henceforth, her relationships with men will be based on her terms. It is as if a spell has been removed from her, and Nguhi paints her new image so vividly: "There was a glint in her eyes that made men's eyes turn to her" (MoG 82). Later, a man follows her, but in her newly found freedom and self-assurance, she snubs him, and he loses his confidence.

Her return to Treetop Bar, the very place where she has been humiliated, is significant, for she must prove a point; she must assert herself, as a liberated being, even though for a brief moment. Nguhi's description of this moment is poignant: "At Treetop Bar ... conversations stopped for a few seconds at her entry ... lascivious eyes were turned to her ... she accepted their drinks as of right. She felt a new power, confidence even" (MoG 83). And Cook and Okenimpke, too, capture this "minute of glory" very effectively:

"She knows what she is doing in returning to the scene

of her former shame and of her theft. She knows that this is a blaze of false glory, a paper conflagration that will burn itself out in a few minutes and leave only ashes. But in these brief moments she has asserted herself (and to the reader) that her lot in life is determined by accidents and external circumstances, not by anything inherent within her"(1983: 150).

The search for self and significance by a woman in the protagonist's situation in a climate which exploits and manipulates women for sexual gratification would appear to be a futile endeavor. The author decries this world that the new Africa 
elite have adopted, a world whose values are in contrast to life that is African and all that it implies. Wanjiru's strength lies in her persistence and constant striving for answers to her problem, not only by engaging in an inner search for who she is but also by actively seeking answers through externally endeavoring to change her appearance. All this contributes to the paradoxically triumphant person she becomes in the end. That she even survives her psychological ordeal could be regarded as a miracle, but, clearly, the portrayal of her endurance and triumph is Nguhi's tribute to the integrity of Gikuyu women. Parallels are shown between Nguhi's heroines, those in his novels being given more scope to develop than those depicted in his short stories. These stories are parables of post-colonial Africa, and Wanjiru's plight is, to me, representative of this era. Although Wanjiru is a fallen woman destined to live in a world removed from her earthly paradise, a milieu associated with warped Western values, she still can have a stake in her destiny. Nguhi wants the reader to see Wanjiru's brief triumph as a gleam of hope for her culture and African women.

NOTES

1. Chinua Achebe's Arrow of God (1964), Things Fall Apart (1978); Ferdinand Oyono's Houseboy (1966), The Old Man and the Medal (1967), to name a few.

2. Ousmane Sembene's works include God's Bit of Wood (1962) and Voltaique (1962), Xala (1974); Aboulaye Sadji's works include Nini: Mulatresse du Senegal (1947) and Maimouna (1958).

3. See Anne Adams Graves, "The Works of Henri Lopes: A Forum for African Women's Consciousness," Ngambika: Studies of African Women in African Literature. Eds. Carole Boyce Davies and Anne Adams Graves. Trenton, New Jersey: Africa World Press, 1986, 131-138.

\section{WORKS CITED}

Achebe, Chinua, and C.L. Innes. African Short Stories. London: Heinemann, 1985.

p'Bitek, Okot. The song of Lawino. Nairobi: East African Publishing House, 1967.

Cook, David, and Michael Okenimpke. Ngugi wa Thiong'o: An Explanation of His Writings. London: Heinemann, 1983 
Davies, Carole Boyce. "Introduction: Feminist Consciousness and African Literary Criticism." Ngambika: Studies of Women in African Literature. Eds. Caroline Boyce Davies and Anne Adams Graves. Trenton, New Jersey: Africa World Press, 1986

Ekwensi, Cyprian. Jagua Nana. London: Heinemann, 1965.

Maupassant, Guy de. "The Necklace." Fictions. 2nd ed. Ed. Joseph S. Trimmer and C. Wade Jenning. New York: Harcourt, 1989.

Mutiso, G-C.M. Socio-political Thought in African Literature: Weusi? New York: Barnes \& Noble, 1974.

Ngugi, James. The River Between. London: Heinemann, 1965.

---. A Grain of Wheat. London: Heinemann, 1967.

Ngugi wa Thiong'o. Petals of Blood. New York: E.P. Dutton, 1978.

---. Devil on the Cross. London: Heinemann, 1982

Nama, Charles. "Daughters of Moombi." Ngambika: Studies of Women in African Literature. Ed. Caroline Boyce Davies and Anne Adams Graves. Trenton, New Jersey: African World Press, 1986.

Smyley-Wallace, Karen. "Women and Alienation: Analysis of the Works of Two Francophone African Novelists." Ngambika: Studies of Women in African Literature. Ed. Carole Boyce Davies and Anne Adams Graves. Trenton, New Jersey: Africa World Press, 1986. 